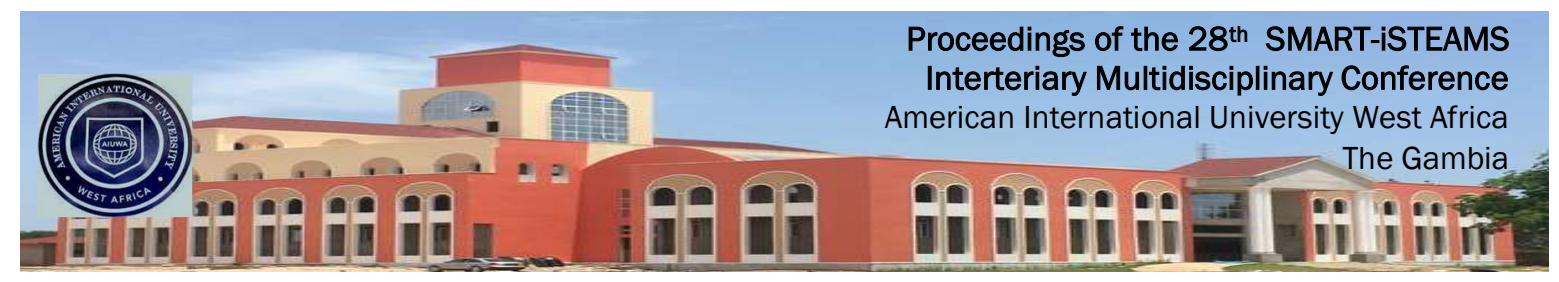

\author{
Full Research Paper
}

\title{
Academic Staff Recruitments and Promotions BY Human Resources Managers at Nigerian Universities: A Case Study of Kaduna State University, Kaduna, Nigeria
}

${ }^{1}$ Ahmed E. Saeed Omar PhD 2Shehu Ibrahim (PhD)

${ }^{1}$ Faculty of Shari'ah \& Islamic Sciences

Alwasl University

United Arab Emirates, Dubai

2Dept of Islamic Studies, Kaduna State University Kaduna, Nigeria

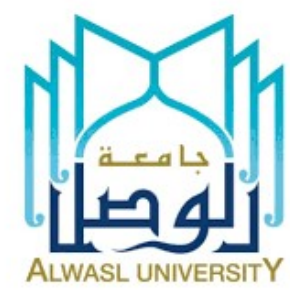

E-mails

1ahmedelmurdi@gmail.com 1ahmedelmurdi@yahoo.com 2ibrahimshehu899@gmail.com

Phones

$+971504751430$

$+2348061503716$

\begin{abstract}
This proposed conference paper which bearing the title of: Academic Staff Recruitments and Promotions by Human Resource Managers At Nigeria Universities: A Case Study of Kaduna State University" Consisting of Introduction and two parts. On the introduction: it discusses historical background, aims and objectives, significance of research, research methodology, research problems, literature review. On part one: The paper will examines Human Resources: It's definition, functions, recruitments and promotions, it's basis and types. Main types of interviews, short listing and application forms. On part two: The researchers explored the practical aspect of recruitments and promotion procedures done by Human Resource Managers in Kaduna State University (KASU) of Nigeria. In the conclusion the paper includes findings and recommendations.
\end{abstract}

keywords: Human Resources, Appointments, Promotion, Interviews, Recruitments, Universities, Nigeria

Proceedings Reference Format

Ahmed E. Saeed Omar \& Shehu Ibrahim (2021): Academic Staff Recruitments and Promotions BY Human Resources Managers at Nigerian Universities: A Case Study of Kaduna State University, Kaduna, Nigeria. Proceedings of the 28th iSTEAMS Intertertiary Multidisciplinary Conference. American Int University West Africa, The Gambia. October, 2021. Pp 11-30. www.isteams.net/gambia2021. DOI - https://doi.org/ 10.22624/AIMS/iSTEAMS-2021/V28N2P2 


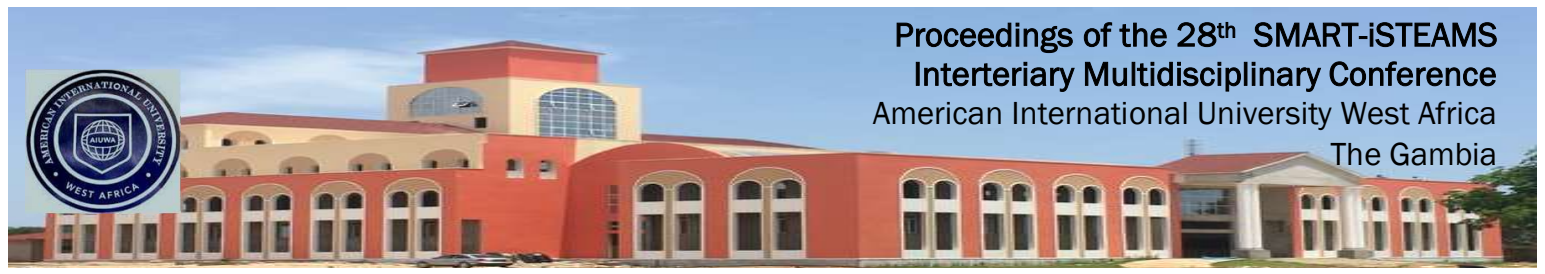

\section{INTRODUCTION}

\subsection{Historical Background:}

The old experience showing the recruitments and promotions style is taking a processes of face interview because of lack of mass media development and progress. In our contemporary era the University Globally having the ability to advertise to annual admission in the available courses at abroad countries, even though some Universities offering online courses for undergraduate degrees and postgraduate studies.

Recently majority of the Universities adopting both direct interview and online process of recruitment and promotions.

\subsection{Aims and objectives:}

The essential aims and objectives that implies by the presentation of this conference paper are the following:

i. To explain to the whole levels of the old and the current temporary style of interviews.

ii. To show the various techniques of internal and external methods of recruitments and promotions.

iii. To explore the very precise, fair and technical standards of a University recruitments and promotions procedures.

iv. To show the absolute fairness by a practical processes through the documentary forms how the human resources managers recruiting and promoting qualified University academic Staff.

v. To provide data on how calculating the criteria that justified recruitments or promotions.

vi. To identify how to evaluate and assess the specialized in a University cadre.

\subsection{Significance of research:}

There are various significances and benefits on conducting or undertaking research under the topic of recruitments and promotions such as:

1. It will expand the influence of the organizations at the external zones and environment.

2. It will enable the organization or the concern institution to recruit qualified staff.

3. It guarantees high degree of fairness and Justice by avoiding in grievance in recruiting or promoting staff.

4. It will provide good opportunities for the new staff to improve their skills and potentials.

5. It will provide new chances for the new appointed staff to get extra level of training and achievement for experiences.

6. It will advertise Nigerian Universities administrative system in the process of recruitments and promotions.

\subsection{Research Methodology:}

For preparation of the forgoing conference paper the researchers adopted (APA) referencing style, in addition to library materials that contains references on managerial sciences with supporting to regulations and guidelines organizing recruitment and selection procedures. 


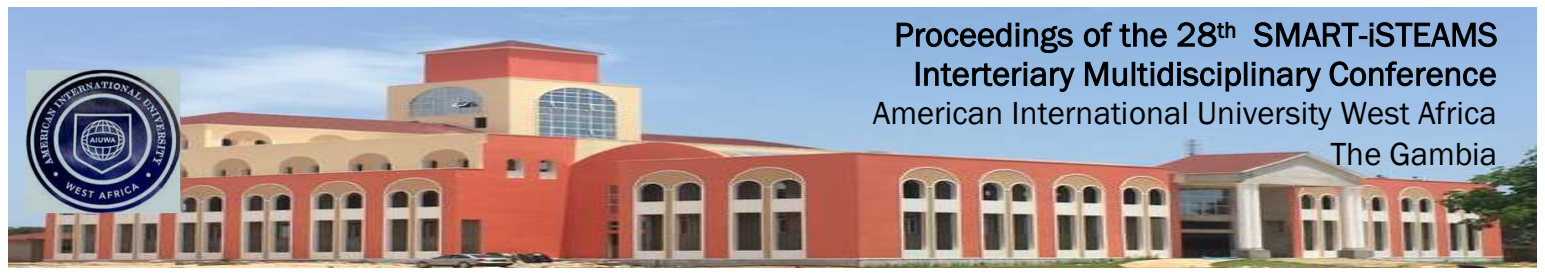

\subsection{Research Problems:}

This paper is in charge to answer different questions arise by the issue of recruitments such as:

i. What is the difference between promotion and selection?

ii. What are the implications of job description job analysis, job specification and job classification?

iii. What are the methods of recruitments?

iv. What are the types of interviews and examination?

v. What are the merit and demerit of recruitment systems?

vi. What is the definition of personal management and it's functions?

vii. What are the standards and measures of recruitments and promotions that adopted by KASU Human Resources managers?

\section{LITERATURE REVIEW:}

The works that written on the role of Human Resource (HR) officers pertaining recruitment and selection in managerial sciences is so immense. The researchers' intent to provide the following:

a. Human Resource Management: Raymond A. Noe. John R. Hollenbeck, Barry Gerhart. Patrick M. Wright, Mc Graw Hill, New York (2003). The researchers examine the Human Resource Planning and Recruitment in chapter (5) where the book analyze and determine Labo demand for various job, discuss advantages and disadvantages of various ways of eliminating surplus of job and describing various recruitment policies.

b. Public Administration: Vishnoo Bhagwono, Vidya Bhushan and Vandana Mohta, Published by S. Chand and Company, New Dalhi (2013). The researchers examine types of personnel systems on pp: 233-289 while recruitment of personnel on pp: 309-327. They provide comprehensive discussion of recruitment problems, such as problems relating to: location of appointment, method of recruitment, types of interviews and examination in addition to the merit and demerit to all these systems.

c. Management Theory and Practice: G.A. Cole, Book power, six edition, London (2003). The book contains details on recruitment and selection on chapter (25). The author on chapter (43) illustrates recruitment policies and procedures; highlighting issues parenting job description, personal characteristics, personal classification and personal specification, the explosion extending to selection processes in particular to application forms and selection interview.

d. Public Administration in Theory and Practice: M.P. Sharma, B.L. Sadana, Harpreet Kawr, published by Kitab Mahal, 49 th repoint (2013). The authors explained personnel administration and human resources development on chapter (19) where they include: meaning, objectives and definition of personnel Management and it's functions in addition to staff selection.

e. Managing Human Resources: Randall. S. Schuler, West Publishing Company. Los Angele and New York (1995). The author discusses on chapter (8) selection and placement, he explains meaning of Human Resources, considerations of choice and selection techniques, interviewing skills and (H.R) advice and application.

f. Human Behavior Management: Gar Dessler Published by Pearson Education, fifth edition, Delhi (2005). The author analyzes human resource or chapter (9) the discussed 


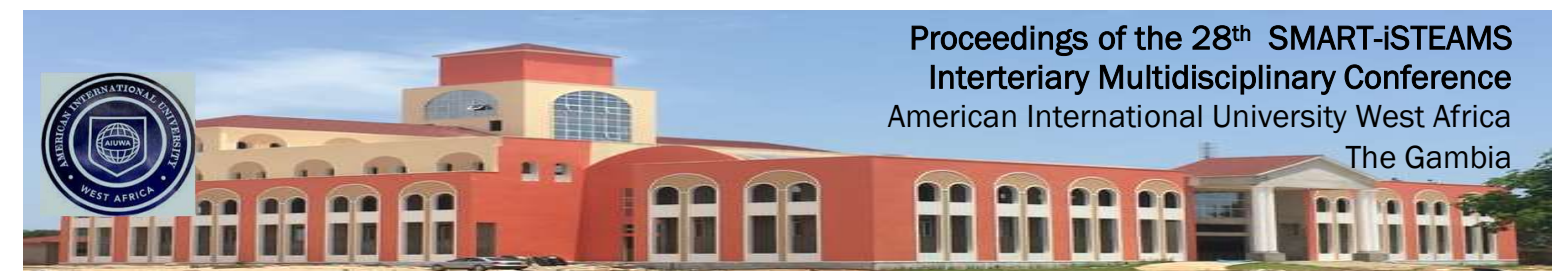

employment planning and forecasting, effective recruitment, inside and outside sources of candidates then employment agencies.

g. Human Resources Management Practice: Michael Armstrong, printed by Bath Press, Bath U.K. and U.S.A eighted edition (2001).

Where the author includes three types of recruitment, job description, personal specification of staff, job classification, choice of system, employees recruitment, analysis of recruitment and sources of candidates.

\subsection{Literature Review Patterning Rules and Regulations Government Human Resources in Kaduna State University (KASU) of Nigeria:}

There are various Nigeria University regulations which governing the human resource function in terms of recruitment and selection such as:-

i. Guidelines for appointment and promotions of Senior Staff Kaduna State University (KASU) office of the Registrar (2015)

ii. Administrative and Academic Regulation in Kaduna State University, September, 2009.

iii. Kaduna State University, Kaduna Staff Condition Service.

iv. Adamawa State University, Mubi: Regulation Governing the conditions of Service for Junior Staff, June, 2005.

\subsubsection{Part One}

2.1.1.1 Human Resources: Definition, Functions, Recruitments or Appointments, it's Basis and Types, Main Types of Interviews, Shortlisting and Application Forms

i. Initial Definition:

a. Recruitment defines as: Preparing job descriptions and specifications, deciding terms and conditions of employment.

b. Promotion defines as: Setting applications, interviewing, testing, assessing candidates, assessment centers, offering employment, obtaining references, preparing contracts of employment, (Michael Armstrong, Ibid p:385).

c. Human Resources: Prof. Cole defines H.F.D as: a process of development of employees through training, performance appraisals, potential, development exercises, communication policies, job enrichment programmes etc. and building of organization climate which may encourage openness, risk taking, role clarity, awareness of employees responsibility, increased communication, improvement of personnel policies, management styles etc. so that employees may be effective in translating their potential energy into. Kinetic energy and the organization may be benefited in terms of better image higher productivity better utilization of resources etc". (S.L. Cole: of cite: p40- M.P. Sharma, B.L. Sanada Harpreet Ibid, p: 450).

d. Job description: According to G.A. Cole is the procedure which containing information about specific job that concern where this kind of information is needed: "Title of the job, grade and salary level, title of immediate superior job, number of subordinate, overall purpose of the job principles and responsibility that offerred by the applicant, limit authorities and location of the job" (G.A. Cole p: 339).

e. Job Specification: Such as seven specifications developed by Professor Roger of National Institute of Industrial Psychology in the 1950s, which including: "Physical make up, attainment, general intelligence, specialized aptitudes, interests, disposition and circumstances, (G.A. Cole, p: 340). 


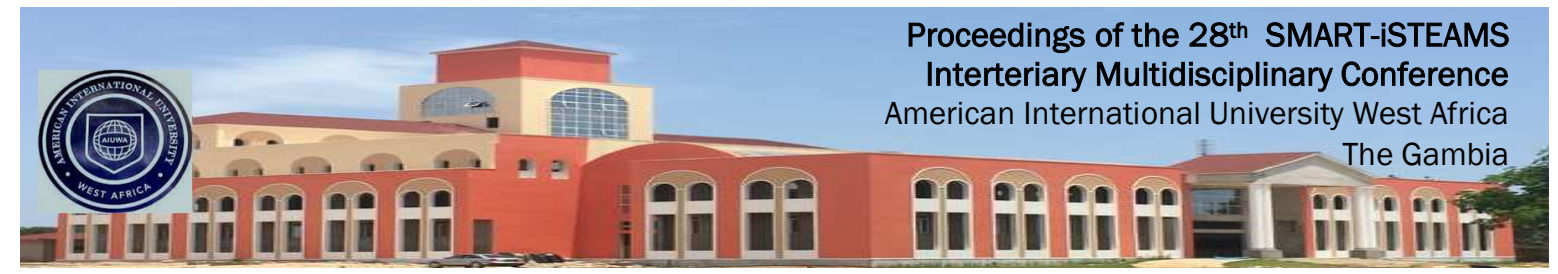

f. Job Classification: It defines as: grouping together of persons on the basis of some common essential characteristic or grouping together of post into broad classes on the basis of work and responsibilities. The posts which bearing similar responsibilities attached and put together in one class in respect to the department in which there are actually located. (M.P. Sharma, Ibid, p: 479).

j. Job Analysis: In most cases majority of the organizations contained these informations in official documents to be completed and it called job analysis.

The requirements of analysis mostly are assuming the sources of the job they contains: Firstly how many jobs are to be filled and around which time? And then information about job descriptions and persons specification qualifications and experiences which are required.

- $\quad$ The secondly: The consideration about where are the suitable candidates from where to come and the destination of the country from where they could be found.

- $\quad$ Lastly to define the terms, the conditions of the service, the payments and benefits, (Michail Armstrong, Ibid, p: 392).

\subsubsection{Human Resources Functions:}

Strauss and sayles: mentioning ten functions to Human Resource Management such as:

(1) Recruitment, Selection and Placement

(2) Job analysis, job description and job evaluation

(3) Compensation and appraisal plans

(4) Employment records

(5) Employment benefit programmes

(6) Special Services

(7) Training and education programmes

(8) Labor relations

(9) Public relations and finally

(10) Personal planning and evaluation (M.P. Sharma Ibid).

\subsubsection{Appointment}

It used in most cases to indicate the term recruitment, which means attracting the proper and suitable qualified staff for filling the post.

\section{Basis of the Appointments:}

1. The process of recruitment should be coordinated and linked with man power plans.

2. The recruitment operation should be part of the personnel functions.

3. The recruitment process should encourage the staff to participation within formation and implementing the plan of recruitment.

4. The recruitment plans should be carefully plan well organized and controlled.

5. The recruitment process should be fair and build the confidence of the applicants.

6. The recruitment methods should use procedures that helped quick disposal of application.

7. The recruitment agencies should exhibits positive interest of the applicants in all process. M.P. Sharma, Ibid p: 457. 


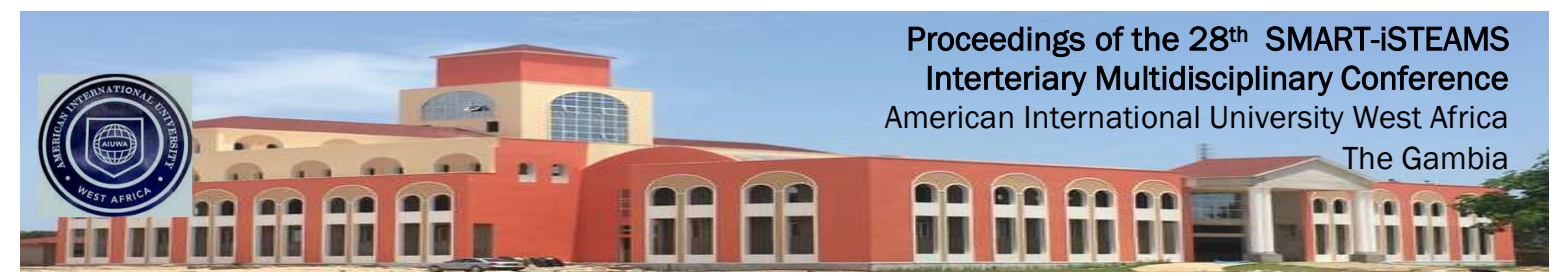

The main types of appointment online site:

There are three types of recruitment:

1. Job site: It is the type of appointment operated by specialized institutions or companies to appoint to their jobs on site which are not normally linked agencies.

2. Agency site: This type of recruitment established by specialized agencies. Candidate may register on line but they may invited to discuss some details before agencies prior their applications forwarded to the employers.

3. Media site: Simply it means a copy of advertisement pasting on the press media it may include recruitment of external staff at abroad countries and the announcement linked to the agency as mediator before the employer Michail Armstrong, Ibid p: 369.

\section{Short Listing Arrangement:}

It is absolutely more necessary to select from the applicants those who appear with their application forms to deserve on interview. If some of the applicant out the country the interviewer may decide who must not come up short list, the common practice is to devide the applications into three groups such as the following:

1. Very suitable: must be invited to attend interview.

2. Quite suitable: deserve to be invited to attend interview if the number of the applications insufficient.

3. Not suitable: The H.R managers should send polite refusal letters to them thanking them for their interest (G.A. Cole, Ibid, p: 341).

\section{Types of Interviews:}

There are two types of interviews:

1. Individual Interview: This type of interview is the most familiar. It implicates face to face discussion. It will enable the interviewers to write the best report about the applicants. The H.R. manager may decide to conduct several interviewers.

2. Interviewing Pariel: According to this types of interview the management will decide two or more people gathering together to interview one candidate. Then the interviewers can discuss their joint before the panel and they may decide their judgment. (Michail Armstrong, Ibid, p: 403).

\section{Application Forms:}

Application forms or letters of application will tell the organization whether the applicant is deserving to be interviewed or invited to attend test or not. This initial step assuming to bed rock for selection and it is prima facia evidence for the suitability of the candidate or it might be point to unsuitability of the candidate. Application who passed this stage successfully they will become eligible to attend the interview. Different organizations may ask the applicant in the forms why are they applying to work in this organization and how are they planning to develop the institution. Therefore, most of the organization prefer to design their own application forms so as to standardize the applicant to fill the forms in the way they likes (G.A. Cole, Ibid, p: 342). 


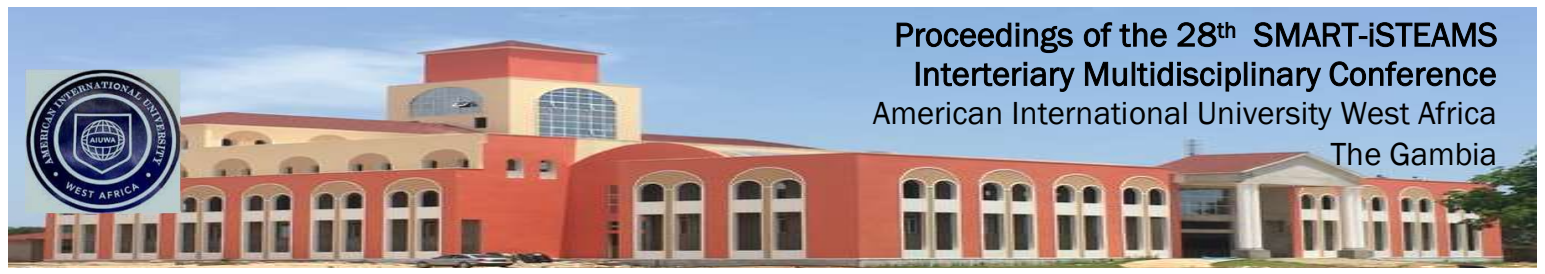

\subsection{Part Two:}

The Practical Aspect of Recruitment and Promotion Procedures Done by Human Resources Managers in Kaduna State University (KASU)

\subsubsection{KASU Profile:}

By this forgoing section the researchers will elaborate Kaduna State of Nigeria the Grade of the University, it's location and population, the establishment of the University, the number of the available Faculties and the total Number of the students.

* Kaduna State is a Nigerian State located in the heart of Nigeria, Kaduna State University (KASU) established on the 21st May, 2004.

* It has Nine Faculties: (1) Faculty of Agriculture (2) Arts and Humanities (3) College of Medicine (4) Faculty of Education (5) Environmental Sciences (6) Management Sciences (7) Pharmaceutical Sciences (8) Faculty of Sciences (9) Faculty of Social Sciences.

* KASU has (48) department

* Academic Staff in KASU about 1107 as at now.

* Number of students about 21,000 including postgraduate students.

* Citizens of Kaduna State about 10,000,000 M.

* Local Government of Kaduna State (23) LG.

\section{Reference (www.kasu.edu.ng-kadunawikipediaforhistoryofkadunastate}

\section{2:2.2 Practical and Operational Procedure of Recruitment and Promotion Done by Human Resources Managers At KASU:}

With reference to Rules: Regulations and guidelines that governing recruitments and promotions such as: Guidelines for Appointments and Promotions of Senior Staff, 2015, Administrative and Academic Regulations in Kaduna State University, 2019 in additions to the Laws that enacted by Kaduna State the Conference paper will illustrate the process or recruitments and promotions to be as follows:

i. Guideline for the Appointments and Promotions of Staff, it's objectives (see section 2).

ii. General Guideline for Appointments and Promotions of Academic Staff (see section 3).

iii. Composition of the appointments and promotions committee and sub committees (see section 4).

iv. Criteria for Appointment and Promotions by Cadres (see section 6).

v. Assessment Form (A), (B) and (C) for the appointment and Promotions of Academic Staff, as cited by Guidelines for Appointments and Promotions of Senior Staff, 2015 pp: 7-28. 


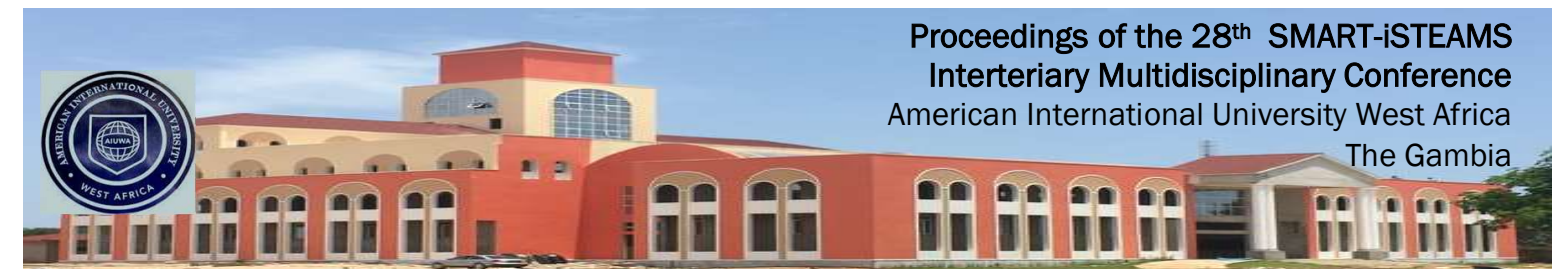

\section{GUIDELINES FOR THE APPOINTMENTS AND PROMOTIONS OF STAFF}

\subsection{Objectives}

The objectives of these guidelines are:

3.1.1 To make the criteria for assessing the performance of staff quantifiable and objective and thus avoid arbitrariness and subjectivity.

3.1.2 To define clear performance targets for staff so as to encourage them to seek to excel in their careers.

3.1.3 To encourage the professional growth of Kaduna State University staff by inducing them to diversify their contributions to the development of the University and thus become well-rounded staff themselves.

\subsection{General Guidelines}

\subsubsection{Appointments}

Council appoints all member of staff other than those for whom a specific method of appointment is otherwise provided, on the recommendation of the appropriate Appointments and Promotions Committee on such terms and conditions as the Council may determine.

\subsubsection{Types of Appointments}

a. Tenure Appointment

Only Nigerians below the age of 50 or as the case may be are eligible for Tenure Appointment, as academic and non-academic staff. These categories of employees are remunerated based on salaries scales, as applicable in the Nigerian University System.

b. Contract Appointment

Generally, non-Nigerians are the category of person employed on contract; however, Nigerians who have retired and whose expertise is required are also employed on contract. These categories of staff are remunerated based on the term of their contract appointment.

c. Visiting Appointment

This is the appointment offered to Academic Staff from other Universities of the ranks of Senior Lecturer/ Senior Research Fellow to Professor/ Research Professor for the purpose of exchange of knowledge for a specific period of time, usually less than one year by the Vice Chancellor on the recommendation of the Head of Department.

d. Full-Time Temporary Appointment

This is the appointment offered to expert in the field or Academic Staff of the ranks of Senior Lecturer/ Senior Research Fellow to Professor/ Research Professor for the purpose of dissemination of knowledge. These categories of employees are remunerated as tenure staff based on their ranks on lesser pay on agreement with them.

e. Temporary Part-Time Appointment

This is the appointment offered to expert in the field or Academic Staff within and in other Universities to complement shortages in academic Departments for the purpose the dissemination of knowledge. These categories or employees are remunerated by the hour based on their ranks. 


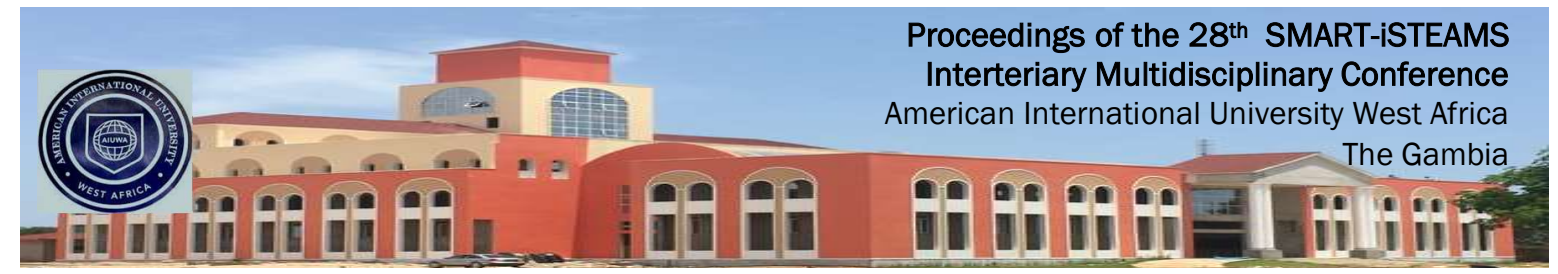

f. Honorary Appointment

This is the appointment offered to experts in the field or Academic Staff of the rank of Senior Lecturer/ Senior Research Fellow to Professor/ Research Professor for the purpose of the dissemination of knowledge.

\subsubsection{Letter Of Appointment}

Letters of appointment are issued by the Registrar or an authorized member of the Administration to whom a Letter of Acceptance shall be sent by the appointee within the specific time stipulated in the Letters of Appointment. The schedule of duty will be as provided by the Head of Department.

\subsubsection{Date Of Assumption Of Duty}

The date an appointed staff takes up appointment is a matter of agreement between him and the University, but the effective date of an appointment is the day the staff assumes duty in his/her assigned place of work. Such date is referred to as 'Date of Assumption'.

\subsubsection{Placement at Employment}

a) New appointees, with years of experience, are placed on appropriate ranks and steps on the basis of their qualifications; previous career experience and performance.

b) For academic staff on the Graduate Assistant grade, a First Class degree places such an employee a step higher than other employees with lower classes of degree.

c) New appointees in professional courses, from five/six year degree programmes, shall be employed as Assistant Lecturers and placed on steps as determined by the duration of the first degree programme.

d) Appointment to the ranks of Associate Professor and Professor are subject to external assessment.

\subsubsection{Confirmation of Appointment}

All senior staff in Tenure Appointment may have their appointments confirmed after a probationary period of two (20) years.

\subsection{Appointments \& Promotions Of Academic Staff}

i. The attainment of the minimum number of points for promotions to any rank does not guarantee the candidate's appointment or promotion as the University reserves as the right to use its discretionary powers.

ii. Promotion to any post is contingent upon the existence of the vacancy.

iii. The minimum period that a candidate must serve in a lower rank before being eligible for consideration for promotion to the next higher rank are as set out below:

a. For Graduate assistant Lecturer -3 years. However, on completion of a higher degree he or she will be upgraded to an appropriate rank and subject to being computer literate. A Lecturer II shall be upgraded to Lecturer I/ Consultant upon the acquisition of the Part II fellowship of a Medical College.

b. $\quad$ For Assistant Lecturer through to Professor grades -3 years each.

iv. Promotion across two ranks (i.e. accelerated promotion/ upgrading) is permitted from Graduate Assistant to Lecturer II subject to the candidate satisfying the minimum requirements for the ranks in view. Candidates seeking direct promotion from Graduate 


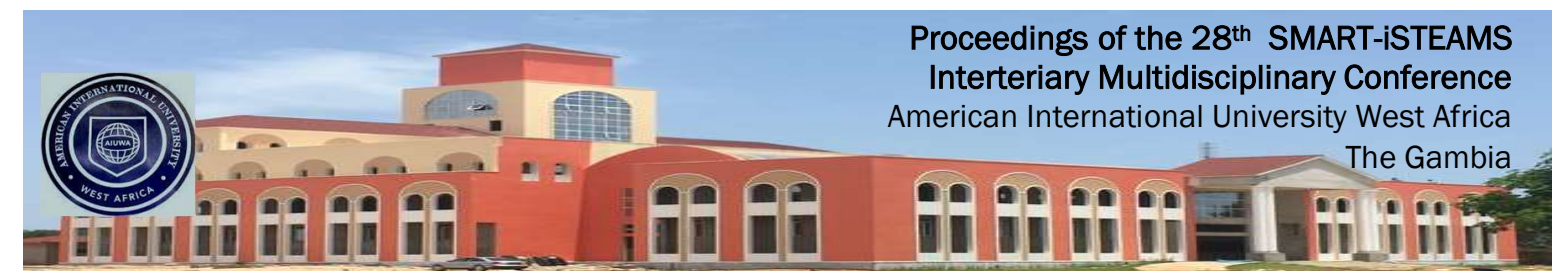

Assistant to Lecturer II shall have obtained a Ph.D. degree. However, accelerated promotions for academic staff can be applicable in two categories.

a. A First Class degree candidate who successfully completes Ph.D. in three years.

b. A Masters' Degree candidate who successfully completes Ph.D.

v. There shall be no accelerated promotion for non-academic staff, except for a Principal Technical Officer II who having stayed for 5 years and has obtained a degree in the relevant field may be considered for promotion to Assistant Chief Technical Officer subject to existence of vacancy and passing the required examinations.

vi. $\quad$ No staff shall be promoted to the rank of Senior Lecturer without a Ph.D.

vii. Promotion to the ranks of Associate Professor and Professor are subject to external assessment.

\subsection{Upgrading}

Academic staff within the Graduate Assistant, Assistant Lecturer and equivalent grades in the Library or research cadre is upgraded administratively to the next higher grade upon the acquisition of a Master's degree or Ph.D. in relevant discipline/ area of specialization by the Vice Chancellor on behalf of the Central Appointments and Promotions Committee, subject to ratification by Council.

\section{COMPOSITION OF THE APPOINTMENTS AND PROMOTIONS COMMITTEE/ SUB-COMMITTEE}

\subsection{Central Appointments And Promotions Committee}

i. Vice Chancellor or External member of Council

ii. Vice Chancellor

iii. Deputy Vice Chancellor (Administration)

vii. Deputy Vice Chancellor (Academic)

viii. 3 members of the Council, two of whom must be external members

ix. Registrar

x. The Dean of Faculty/ Director/ HOD

Quorum

xi. Establishment Secretary

Chairman

Member

Member

Member

Members

Member

Member

Secretary

i. The Chairman

ii. One External member of Council

iii. Three other members, one of which is a Senate representative

\subsection{Faculty Appointments And Promotions Committee}

There shall be Faculty Appointments and Promotions Committee, which shall comprise the following:

4.2.1 Dean of the Faculty (Chairman)

4.2.2 All Heads of Departments in the Faculty

4.2.3 Two members representing Faculty Board to be elected by the Faculty Board who shall not be below the rank of Senior Lecturer.

4.2.4 Elected representatives of Faculties on Faculty Appointment and Promotions.

4.2.5 The Faculty Officer shall be in attendance as the Secretary.

4.2.6 The representative of the Establishment Secretary shall be in attendance 


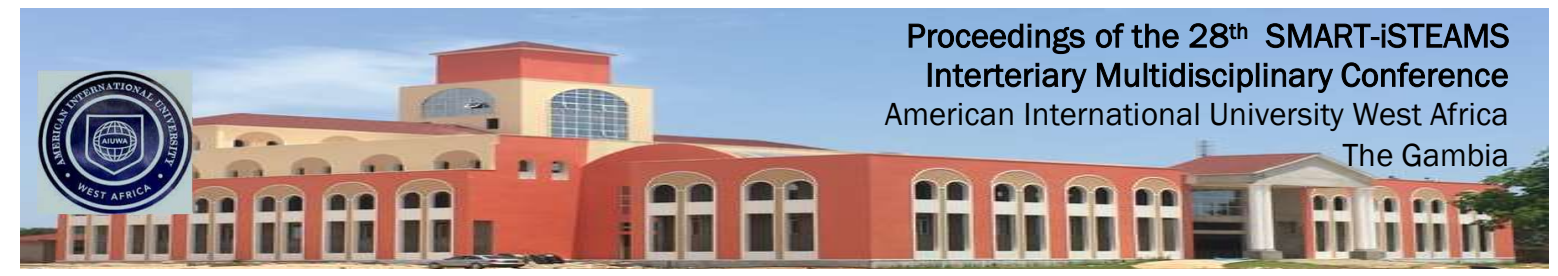

Quorum

$1 / 2$ of the membership including the Chairman.

\subsection{Functions of Faculty Appointments and Promotions Committee}

The Faculty Appointments and Promotions Committee shall have the following functions:

4.3.1 Reviewing of Departmental Appointments and Promotions Committee's assessment and recommendations for promotions;

4.3.2 Dispassionate adjudication in matters of disagreement between the Department Appointments and Promotions Committee and a candidate for promotion, or confirmation or renewal of contract or any combination of the above; in any of these cases, the candidate shall have the right to initiate action by writing directly to the Committee and shall have the right to fair hearing in cases of adverse comment by the Departmental Appointment and Promotions Committee;

4.3.3 Performing the role of a Clearing House for submissions to the Central Appointments and Promotions Committee for all promotion cases. No submission shall be entertained by the Central Appointments and Promotions Committee unless it is routed through the Faculty Appointments and Promotions Committee.

4.3.4 Members of a Faculty Appointments and Promotions Committee shall not sit on the Committee when their cases are being considered.

4.3.5 No case shall be discussed in a specific department in the absence of the Head of Department or his representative.

4.4 Department Appointments and Promotions Committee There shall be Department Appointments and Promotions Committee with the following composition:

\subsubsection{The Head of Department (Chairman)}

4.4.2 Not more than 30\% of the staff of the Department elected for a period of one year. Staff qualified should be not below the rank of Senior Lecturer and above. A member is eligible for re-election for another year. Where not available, staff on the rank of Lecturer I or II may be considered.

4.4.3 A member shall not sit on the Committee when his case is being considered for promotion. 


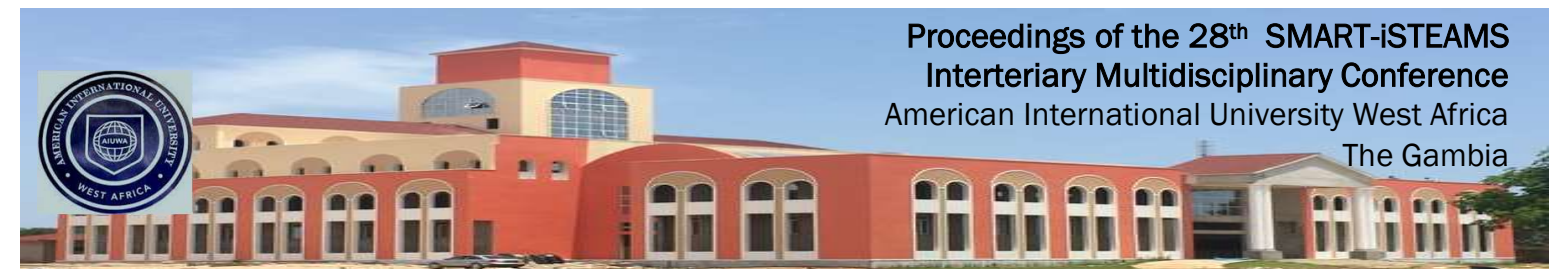

\subsection{Functions of Department Appointments and Promotions Committee}

Departmental Promotions Committee shall have the following functions:

4.5.1 Verification and assessment of all claims made in a candidate's curriculum vitae including assessment of all publications cited therein.

4.5.2 To consider and recommend to the Faculty Appointments and Promotions Committee all cases of Promotions of Academic staff.

4.5.3 To review the status of every staff member in the Department annually with a view to recommending those who are suitable and eligible for promotion.

\section{SUMMARY OF THE DISTRIBUTION OF POINTS}

Qualifications -

Teaching -

Publications

Administration \& Community Services -

TOTAL
10 points

30 points

10 points

- 40 points

10 points

100 points

\section{CRITERIA FOR APPOINTMENTS AND PROMOTIONS BY CADRES}

\subsection{ACADEMIC STAFF IN THE KADUNA STATE UNIVERSITY}

i. Graduate Assistant

CONUASS 1

(A) To be appointed to this position, a candidate must possess: Bachelors degree with First Class or Second Class Upper Division in relevant discipline

ii. $\quad$ Assistant Lecturer CONUASS 2

(A) To be appointed to this position, a candidate must possess: Either B.Pharm Or M.Sc./M.A in relevant discipline

(B) A Graduate Assistant shall be upgraded to Assistant Lecturer upon the acquisition of a Masters' degree.

If the candidate fails to do so at the end of the three years waiting period between promotions, candidate's appointment may be terminated.

iii. Lecturer II CONUASS 3

(A) To be appointed to this position, a candidate must possess:

$\checkmark$ Either Ph.D. in relevant discipline Or Masters' degree in relevant discipline

$\checkmark 3$ Conference/ Seminar papers

$\checkmark$ At least 4 years teaching experience in a University

(B) An Assistant Lecturer with B.Pharm shall be upgraded to Lecturer II upon the acquisition of a Master's degree. 


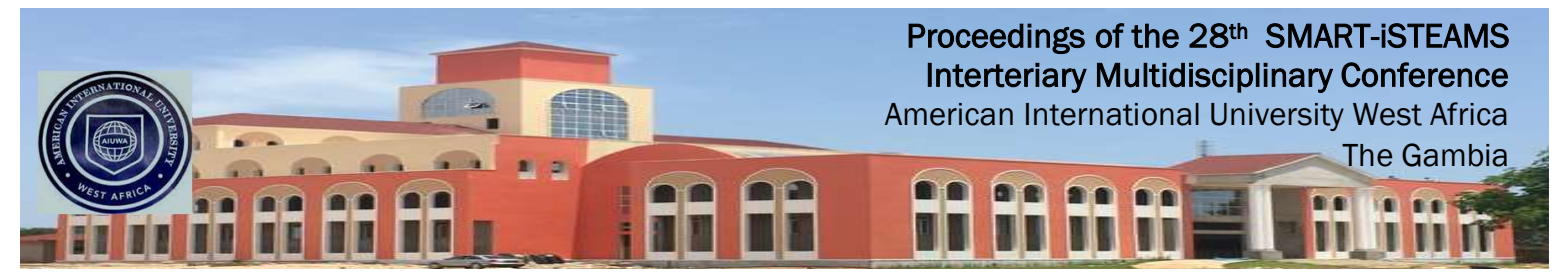

If the candidate fails to do so at the end of the three years waiting period between promotions, candidate's appointment may be terminated.

(C) For promotion of Lecturer II, an Assistant Lecturer must:

$\checkmark$ Spend a minimum of 3 years as an Assistant Lecturer,

$\checkmark$ Possess the Masters' degree in the relevant discipline

$\checkmark 2$ Conference Papers

$\checkmark$ Favourable Recommendation by the Head of Department

iv. Lecturer I CONUASS 4

(A) To be appointed to this position, a candidate must possess:

Either

$\checkmark$ Ph.D. in relevant discipline

$\checkmark 2$ points in Publication provided that 1 point must be earned from journal publication

$\checkmark 3$ Conference/ Seminar papers

$\checkmark$ At least 3 years teaching experience in a University or Masters' degree in relevant discipline

$\checkmark \quad 3$ points in Publications provided that 1 point must be earned from journal publication

$\checkmark 3$ Conference papers

$\checkmark$ At least 6 years teaching experience in a University

(B) For promotion to Lecturer I, a Lecturer II must

$\checkmark$ Spend a minimum of 3 years as Lecturer II

$\checkmark 2$ points in Publications provided that I point must be earned from journal publication

$\checkmark \quad 2$ learned Conference/ Seminar Papers

$\checkmark$ Favourable recommendation by the Head of Department

$\checkmark$ To be eligible for promotion to Lecturer I, a candidate must score a minimum of 6 points solely on the basis of qualification or score a minimum of 15 points.

v. Senior Lecturer CONUASS 5

(A) To be appointed to this position, a candidate must possess:

$\checkmark$ Ph.D. in relevant discipline

$\checkmark 6$ points in Publications provided that 4 points must be earned from journal publications.

$\checkmark 4$ Conference papers

$\checkmark$ At least 3 years teaching experience in a University.

(B) For promotion to Senior Lecturer, a Lecturer I must:

$\checkmark$ Spend a minimum of 3 years as Lecturer I,

$\checkmark$ Possess Ph.D.

$\checkmark$ Possess the requisite qualifications for the rank of Senior Lecturer

$\checkmark 6$ points in Publications provided that 4 points must be earned from journal publications.

$\checkmark \quad 4$ learned Conference/ Seminar Papers. 


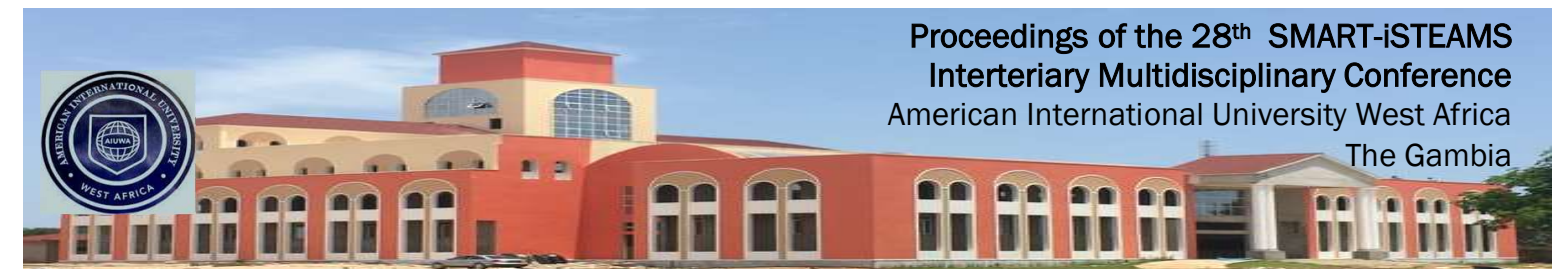

vi. Associate Professor CONUASS 6

(A) To be appointed to this position, a candidate must possess:

$\checkmark$ Ph.D. in relevant discipline

$\checkmark 10$ points in Publications provided that 6 points must be earned from journal publications

$\checkmark 5$ Conferences papers

$\checkmark$ At least 6 years teaching experience in a University

The appointment shall be subject to external assessment, if not already an Associate Professor from a reputable University

(B) For promotion to Associate Professor, a Senior Lecturer must:

$\checkmark$ Spend a minimum of 3 years as Senior Lecturer,

$\checkmark$ Possess Ph.D.

$\checkmark$ Possess the requisite qualifications for the rank of Associate Professor

$\checkmark 10$ points in Publications provided that 6 points must be earned from journal publications

$\checkmark 5$ learned Conference/Seminar Papers/ chapters in a book

$\checkmark$ Subject to external assessment

$\checkmark$ To be eligible for promotion to Associate Professor, a candidate must score a minimum of 40 points, including a minimum of 4 points on the basis of community service.

\section{vi. $\quad$ Professor CONUASS 7}

(A) To be appointed to this position a candidate must possess:

$\checkmark$ Ph.D. in relevant discipline

$\checkmark 15$ points in Publications provided that 10 points must be earned in journals publications

$\checkmark \quad 7$ Conference papers

In addition to the above,

$\checkmark$ Community service

$\checkmark$ At least 9 years teaching experience in a University

The appointment shall be subject to external assessment.

(B) For promotion to Professor, an Associate Professor must:

$\checkmark$ Spend a minimum of 3 years as Associate Professor,

$\checkmark$ Possess Ph.D. equivalent

$\checkmark$ Possess a the requisite qualifications for the rank of Professor

$\checkmark 15$ points in Publications provided that 10 points must be earned from journal publications

$\checkmark 7$ learned Conference/Seminar Papers/ chapter in a book

$\checkmark$ Postgraduate supervision

$\checkmark$ Community service/ Administrative duties

$\checkmark$ Subject to external assessment 


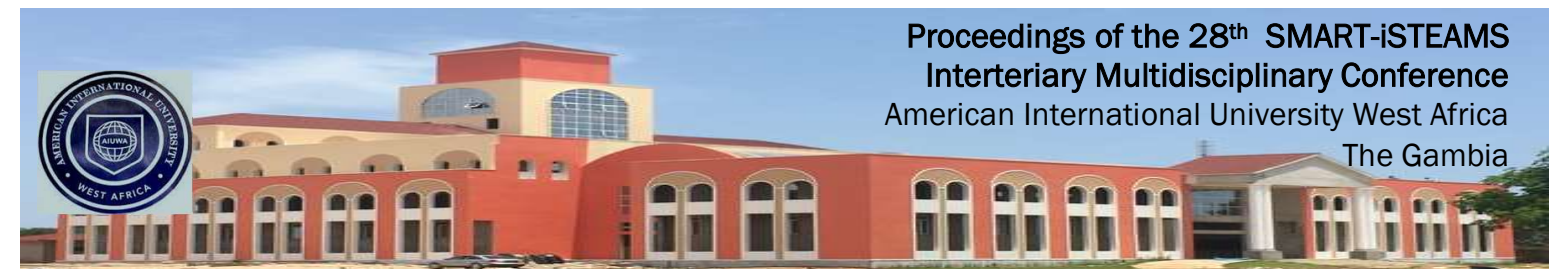

$\checkmark$ To be eligible for promotion to Professor, a candidate must score a minimum of 55 points, including a minimum of 5 points on the basis of community service.

\subsection{Medically Qualified Staff In The Clinical Section}

i. $\quad$ Assistant Lecturer CONUASS 2

(A) To be appointed to this position a candidate must possess: MBBS

ii. Lecturer II CONUASS 3

(A) To be appointed to this position a candidate must possess:

MBBS

Part I Fellowship of Medical Colleges

iii. Lecturer I CONUASS 4

(A) To be appointed to this position a candidate must possess:

MBBS

Part II Fellowship of Medical Colleges

(B) A Lecturer II shall be upgraded to Lecturer I/ Consultant upon the acquisition of the Part II fellowship of Medical Colleges.

iv. Senior Lecturer CONUASS 5

(A) To be appointed to this position a candidate must possess:

$\checkmark$ MBBS

$\checkmark$ Part II final Fellowship of Medical Colleges

$\checkmark 6$ points in Publications provided that 4 of the points must be earned in journal publications

$\checkmark 4$ Conference papers

$\checkmark$ At least 3 years teaching experience in a University

(B) For promotion to Senior Lecturer, a Lecturer I must:

$\checkmark$ Spend a minimum of three (3) years as lecturer I,

$\checkmark 6$ points in publications provided that 4 of the points must be earned in journal publications

$\checkmark 4$ Conference papers.

v. Associate Professor

CONUASS 6

(A) To be appointed to this position a candidate must possess:

$\checkmark$ MBBS

$\checkmark$ Part II final fellowship of Medical Colleges

$\checkmark 10$ points in publications provided that 6 of the points would be in journal publications

$\checkmark 5$ Conference papers

$\checkmark$ At least 6 years teaching experience in a University

The appointment shall be subject to external assessment, if not already an Associate Professor from a recognized University. 


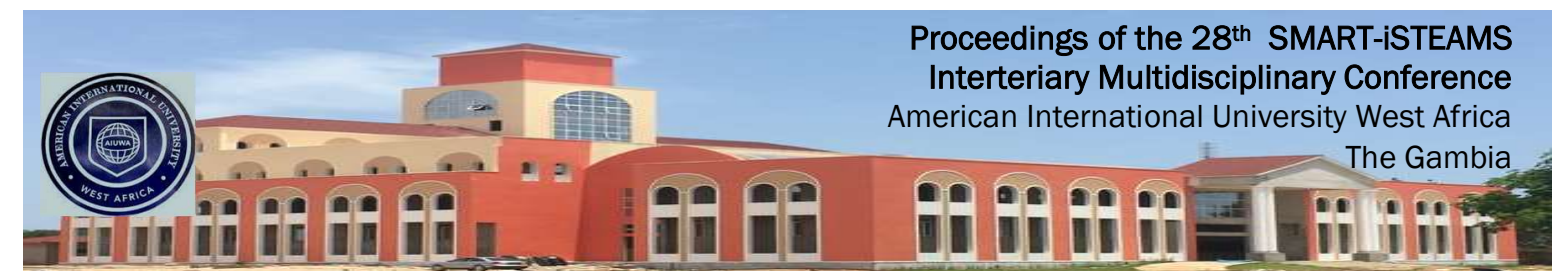

(B) For promotion of Associate Professor, a Senior Lecturer must:

$\checkmark$ Spend a minimum of three (3) years as Senior Lecturer,

$\checkmark 10$ points in publications provided that 6 points must be earned in journal publications;

$\checkmark 6$ Conference papers

$\checkmark$ Community service/ Administrative duties

$\checkmark$ Subject to external assessment

$\checkmark$ To be eligible for promotion to Professor, a candidate must score a minimum of 40 points, including a minimum of 5 points on the basis of community service.

vi. Professor CONUASS 7

(A) To be appointed to this position a candidate must possess:

$\checkmark$ MBBS

$\checkmark$ Part II final fellowship of Medical Colleges

$\checkmark 15$ points in publication provided that 10 points must be earned in journal publications;

$\checkmark 7$ Conference papers

$\checkmark$ At least 9 years teaching experience in a university

The appointment shall be subject to external assessment, If not already a Professor

(B) For promotion to Professor, an Associate Professor must:

$\checkmark$ Spend a minimum of three (3) years as Associate Professor,

$\checkmark 15$ points in publications provided that 4 of the points must be earned in journal publications;

$\checkmark 7$ Conference papers

$\checkmark$ Postgraduate supervision

$\checkmark$ Community service/ Administrative duties

$\checkmark$ Subject to external assessment

$\checkmark$ To be eligible for promotion to Professor, a candidate must score a minimum of 55 points, including a minimum of 5 points on the basis of community service.

\subsection{Medically Qualified Staff In The Pre-Clinical Level}

i. Assistant Lecturer CONUASS 2

(A) To be appointed to this position a candidate must possess: MBBS

\section{ii. Lecturer II CONUASS 3}

(A) To be appointed to this position a candidate must possess: MBBS, Masters' degree in relevant discipline

(B) An Assistant Lecturer shall be upgraded to Lecturer II upon the acquisition of a Master's degree

If he/she fails to do so at the end of three years waiting period between promotions, his/her appointment may be terminated 


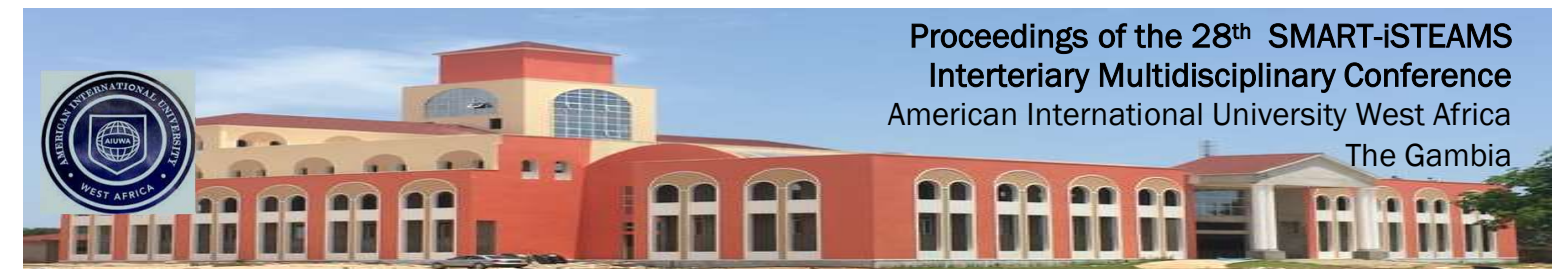

iii. Lecturer I CONUASS 4

(A) To be appointed to this position a candidate must possess:

Either

$\checkmark$ An MBBS and Ph.D. in relevant discipline or MBBS and M.Sc. with minimum of 3 years teaching in the University

$\checkmark \quad 2$ points in Publication provided that I point must be earned in journal publications

$\checkmark 3$ Conference papers

$\checkmark$ At least 3 years teaching experience in a University

(B) For promotion to Lecturer I, a Lecturer II must:

$\checkmark$ Spend a minimum of three (3) years as Lecturer II,

$\checkmark 2$ points in Publication that I point must be earned in journal publications

$\checkmark 3$ Conference papers

iv. Senior Lecturer CONUASS 5

(A) To be appointed to this position a candidate must possess:

$\checkmark$ MBBS and Ph.D. in a relevant discipline

$\checkmark 6$ point in Publications provided that 4 points must be earned in journal publications

$\checkmark$ At least 3 years teaching experience in a University

$\checkmark$ Computer literacy

(B) For promotion to Senior Lecturer, a Lecturer I must:

$\checkmark$ MBBS and Ph.D. in a relevant discipline

$\checkmark$ Spend a minimum of three (3) years as Lecturer I

$\checkmark 6$ point in Publications provided that 4 points must be earned in journal publications

$\checkmark \quad 4$ Conference papers

v. Associate Professor CONUASS 6

(A) To be appointed to this position a candidate must possess:

$\checkmark$ MBBS and Ph.D. in a relevant discipline

$\checkmark 10$ point in Publications provided that 6 points must be earned in journal publications

$\checkmark 5$ Conference papers

$\checkmark$ At least 6 years teaching experience in a reputable University

The appointment shall be subject to external assessment, If not already an Associate Professor

(B) For promotion to Senior Lecturer, a Lecturer I must:

$\checkmark$ MBBS and Ph.D. in a relevant discipline

$\checkmark$ Spend a minimum of three (3) years as Senior Lecturer

$\checkmark 10$ point in Publications provided that 6 points must be earned in journal publications

$\checkmark 5$ Conference papers

$\checkmark$ Postgraduate supervision 


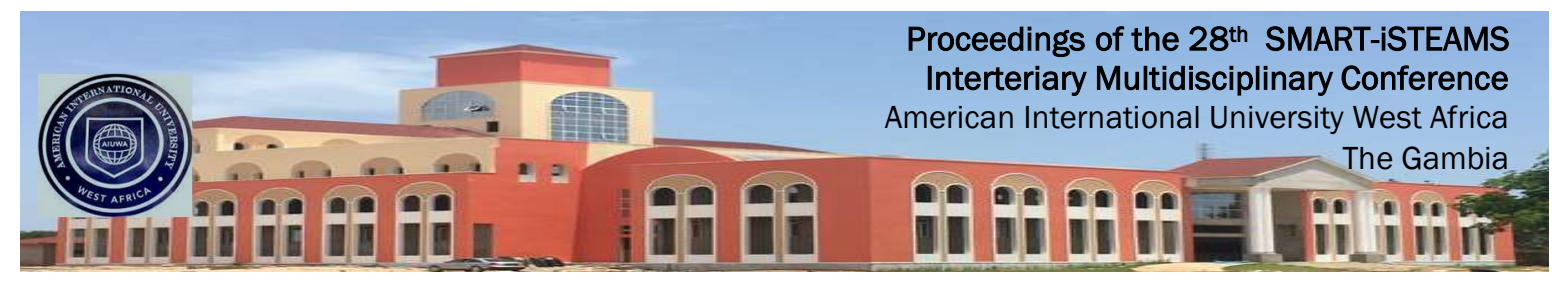

$\checkmark$ Community service/Administrative duties

$\checkmark$ Subject to external assessment

$\checkmark$ To be eligible for promotion to Professor, a candidate must score a minimum of 40 points, including a minimum of 5 points on the basis of community service.

i. Professor CONUASS 7

(A) To be appointed to this position a candidate must possess:

$\checkmark$ MBBS and Ph.D. in a relevant discipline

$\checkmark 15$ point in Publications provided that 10 points must be earned in journal publications

$\checkmark 7$ Conference papers

$\checkmark$ At least 9 years teaching experience in a University

The appointment shall be subject to external assessment, If not already a Professor

(B) For promotion to Senior Lecturer, a Lecturer I must:

$\checkmark$ MBBS and Ph.D. in a relevant discipline

$\checkmark$ Spend a minimum of three (3) years as Associate Professor

$\checkmark 10$ point in Publications provided that 6 points must be earned in journal publications;

$\checkmark 7$ Conference papers

$\checkmark$ Postgraduate supervision

$\checkmark$ Community service/ Administrative duties

$\checkmark$ Subject to external assessment

$\checkmark$ To be eligible for promotion to Professor, a candidate must score a minimum of 55 points, including a minimum of 5 points on the basis of community service. 


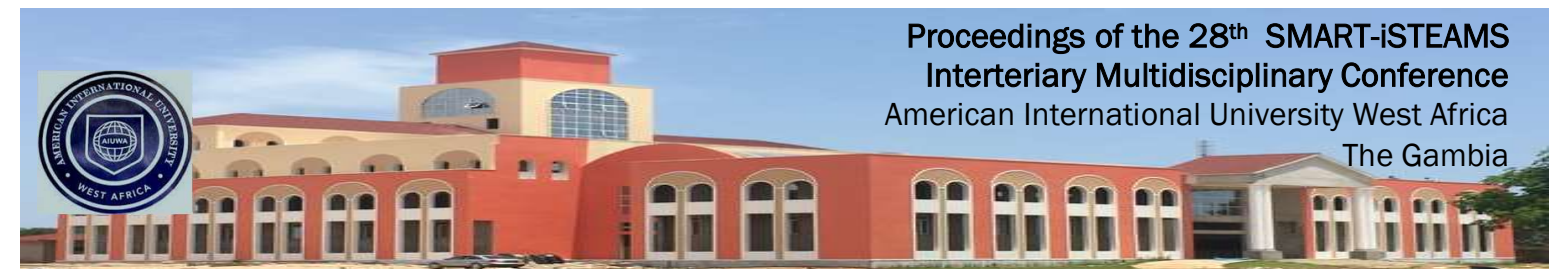

\section{FINDINGS}

What follows are findings from the research

1. Policies and procedures of recruitment and promotion in which stated lay human resources managements are the one that implemented by Kaduna State University.

2. The practical procedures and policies that states by KASU in terms of recruitment and promotions granted for the school to employ qualified academic staff.

3. The strategic location of KASU and Kaduna State which cited in the heart of Nigeria enable the school to attract both foreign and indigene academic staff.

4. The Kanye National Resources mineral agricultural and industrial resources if Kaduna State supported financially KASU to spend the school in the coming decades.

5. The conducive atmosphere and the medicate temperature of the whether encouraged the researchers and the scholars to produce very standing and tangible research.

\section{RECOMMENDATIONS}

The researchers would like to state the following recommendations

1. Universities administration may establish separate departments for Human Resources enable them with various regulations to run the activities and process of recruitments and promotions.

2. Universities Administration may reduce the accumulation of various responsibilities which already took in the burden of offices of registrar or department of establishment to be handle over to department of Human Resources.

3. The Hange documentation of files regarding recruitment promotions transfer offering loans, sabbatical, visiting lecturers, offering pension, redundancy action etc... may transfer from the office of registrar to department of (H.R) 


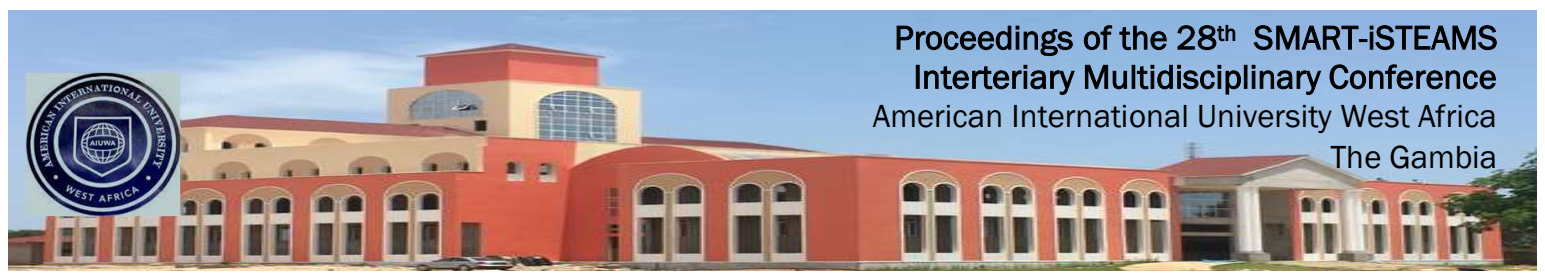

\section{REFERENCE}

1. G.A. Cole: (2003), Management Theory and Practice, Book power London, six edition.

2. Rondall S. Schuler: (1995), Managing Human Resources, West Publishing Company, New York.

3. Michael Armstrong: (2001), Human Resources Management Practice, $8^{\text {th }}$ edition, Bath Press.

4. M.P. Sharma, B.L. Sanada, Harpreet: (2013), Public Administration in Theory and Practice, Kitab Machal Delhi, 49 Reprent.

5. Vishnso Shagwan, Vidya Buhshan, Vandana Mohla: (2008), Public Administration, S. Chand and Company, Delhi.

6. Gary Dessler: (2005) Human Behviour Management, Ninth edition, Preason Education, Singapor, sixth edition.

7. Raymond A. Noe, John R. Hollenbeck, Garry Gerhart, Patrick M. Wright: (2003), Human Resource Management, Mc Graw-Hill, New York.

8. Guideline for Appointments and Promotions of Senior Staff, Kaduna State University, (KASU) office of the Registrar (2015).

9. Kaduna State University Staff conditions of service.

10. Administrative and Academic Regulations in Kaduna State University, September (2019). 